and nomenclature, habitat, part used, active principles, therapeutical properties, pharmacology and chemical composition. With the loss-important medicinal plants one or two pages only are devoted to them, but with the more important species a great deal more space is given, especially to their chemistry, all the latest information having boen assembled or brought together. As an example, one may take digitalis (Digitalis purpurea), to which 30 pages are devoted, including an up-to-date bibliography of 215 referencos. Digitalis lanata occupies 23 pages with 95 references. Among the non-European or tropical drug plants doalt with in this volume are star anise, boldo, buchu, cannabis, cardamom, cascara, cinchona, coca, cola, Calabar bean and ginseng. To anyone engaged in pharmacological work and able to road Italian, this should prove a useful refereneo work.

The South African book is a revised and greatly enlarged edition of the now well-known work by Watt and Breyer-Brandwijk (The Medicinal and Poisonous Plants of Southern Africa) that first appearod in 1932. Since that time a great deal of knowledge has accumulated on the poisonous and medicinal plants of South and East Africa, and it is in every way desirable that a new edition of this book should now appear. The book shows little resemblance to its illustrious predecessor, being more than four times as large and consisting of 1,455 pages, as against 314 pages for the original edition. It now weighs $7 \frac{1}{2} \mathrm{lb}$. ! Unfortunately, this greatly increased sizo has to be reflected in the price of the book.

As indicated in the title and subtitle, the work deals with the medicinal and other uses, chemical composition, pharmacological effects and toxicology in man and animal of the medicinal and poisonous plants of southorn and eastern Africa. The appearance of this new exhaustive and scholarly work is especially appropriate at the present time in view of the fact that much of the folk-medicine of the indigenous peoples of Africa is undoubtedly disappearing before the advancing tide of civilization. Some foel that much of it may have disappeared altogether within measurable time. This is also happening in other parts of the world. The detailod index (occupying 258 pages) is a valuable feature of the book, including as it does native, Afrikaans and English names of plants. This new edition is much more freely illustrated than the first edition and includes pleasing coloured plates. F. N. Howes

\section{BIRDS OF NORTH AMERICA}

Handbook of North American Birds

Edited by Ralph S. Palmer. Vol. 1: Loons through Flamingos. Pp. vii $+567+6$ plates. (Now Haven, Conn., and London: Yale University Press, 1962.) $105 s$. GOR some thirty years British, and indeod Euro-
pean, ornithologists have had a standard work of reference in the five volumes of the Handboole of British Birds by H. F. Witherby and others. Now an equivalont work for North America has been launched under the auspicos of the American Ornithologists' Union, in association with the Now York State Museum and Science Service. This is expected to run to at least six volumes, over a number of years; the first has now boen published. Important advances in ornithological knowledge have been made since the older work was published, and in the new one it is interosting to note the shifts of emphasis on different facets. In particular, the systematic treatment in this work is based on species, whereas the earlier one was the victim of a passing fashion for regarding the subspecies (or geographical race) as the biological entity.

The area covered comprises Greenland, Canada, the United States (including Alaska, but, of course, not Hawaii), and a few islands such as the Bermudas. This is something less than the classical Nearctic region, which takes in the northern part of Mexico; even the isolated Mexican peninsula of Baja California, in the area of the American Ornithologists Union Check-list, is here excluded. Following a practice that is likewise common in British birdbooks, species that are only rare vagrants to the area are given full treatment. Tho relevant subspecies are dealt with quite briefly: extralimital forms are just listed.

Commendable care is taken at the outset to define terms. An illustrated section on colour specification is especially noteworthy. The terminology of successive plumages and moults is explained, equating new and old names. Methods of measurement and the topography of the body-surface are the subjects of clear diagrams. The definitions of vowel and consonant sounds in vocalization follow the late Bernard Tucker of Oxford. Othor definitions relate to types of pair-bond (including multiple sexual nexus) and shapes of 'egg profile'.

The systematic treatment includos, for oach species, detailed description of plumage, points for field identification, and the characteristics of voice; habitat, range and migration (with a statement of 'banding status'); roproductivo behaviour, eggs, young and 'survival data'; general habits and food. The last mentioned is based mainly on the ascertained stomach contents or castings and with as quantitative an approach as the evidence permits.

Although no policy as regards illustrations is explicit, a new tendency for a work of this kind is evident. No attempt is made to portray every species, but some are shown in drawings that give a good impression of the character of the bird. Colour is used only to bring out special points; a plate illustrating seasonal changes in the bill, iris and foot in certain heron species is particularly valuable. On the other hand, black-and-white maps of distribution are used lavishly; and there are some whole pages of usoful diagrammatic drawings of various display postures of single species. These reflect a modern geographical and ethological approach to bird study.

Dr. Ralph Palmer (of the Stato Musoum at Albany) is to be congratulated on his first volume, and on the manner in which he has integrated the numerous contributions by specialists. At this end of the taxonomic spectrum there is an absence of peculiarly New World groups. Thus tho loons (that is, divers) are circumpolar, the grebes are at most generically distinct, the petrels inhabit the oceans of the world, and tho totipalmate families are cosmopolitan. In North America the last mentioned include quite a number of cormorant species, an anhinga not unlike the darter of Africa, and a marine pelican that plunges on its prey from flight like a gannet. The herons are strongly represented, the storks poorly, and there are a few ibises. Finally, there is one flamingo-usually regardod as conspecific with that found in parts of Europe and Africa, but showing a deeper pink.
LANDSBOROUGH THOMSON 